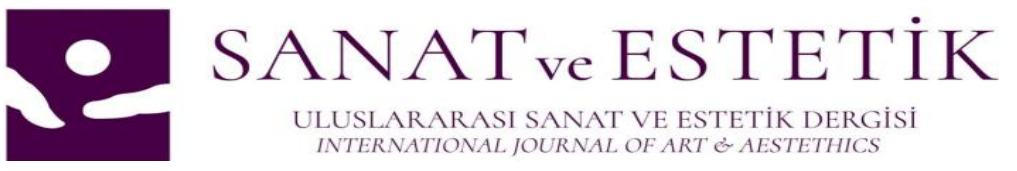

Uluslararası Sanat ve Estetik Dergisi Y11:3, Sayı:4, Haziran 2020

Yayın Geliș Tarihi / Article Arrival Date 19.04.2020
Yayınlanma Tarihi / The Publication Date 30.06.2020

\title{
Bilim Uzmanı Gökçe Oruç
}

Bu çalışma 2018 yılında Prof. Dr. Serpil Bağcı danışmanlığında hazırlanan, İstanbul'dan Paris'e: Hüseyin İstanbuli'ye Atfedilen Bir Kıyafetname. Başlıklı yüksek lisans tezinden derlenmişstir.

Hacettepe Üniversitesi Sanat Tarihi Bölümü

gokceoruc91@ hotmail.com ORCID: 0000-0002-6922-8025

\section{ISTANBUL'DAN PARIS'E GIZEEMLİ BİR YOLCULUK: HÜSEYIN ÍSTANBULI'YE ATFEDİLEN KIYAFET ALBÜMLERİ}

\section{$\ddot{\mathbf{O Z}}$}

$\mathrm{Bu}$ çalışmada; Osmanlı toplumundan çeşitli kesitleri sunan resim antolojileri olarak tanımlayabileceğimiz 15.yüzyıl sonunda ortaya çıkan ve 17. yüzyılda yaygınlaşan genellikle saray dışında üretilmiş olan kıyafet albümlerinden biri Osmanlı resim sanatı bağlamında incelenmektedir. Bugün Paris Bibliothèque Nationale de France koleksiyonunda (N.Od.7) bulunan 1688 tarihli klyafet albümü Saray nakkaşhanesi mensubu olan Musavvir Hüseyin İstanbuli tarafından hazırlanmıştır. Resimlerinde imza bulunmayan bu albümler, sanatçının bilinen imzası bulunan Silsilenamelerdeki resimleriyle ve günümüzde İstanbul Nadir Eserler Koleksiyonunda yine kendisine atfedilen eserlerle üslup ve ikonografi açısından karşılaştırmalı olarak tartış1larak ona atfedilmiştir. İncelenen albümün ve Hüseyin'in 17. yüzyıl'ın ortalarında üretilmiş diğer kıyafet albümlerine üslup ve ikonografi açısından bazı yenilikler getirdiği saptanmıştır.

Araştırmaya konu olan klyafet albümü içerisinde 60 resim vardır ve resim programı içinde Padişah, Vezir-i Azam, diğer saray görevlileri, halktan kadın ve erkekler, hokkabaz, dervişler ve din adamları yer almaktadır. Avrupa beğenisi ve talebinin getirisi olan kıyafet 


\section{İSTANBUL'DAN PARİ'E GIZZEMLİ BİR YOLCULUK: HÜSEYİN İSTANBULI'YYE ATFEDİLEN KIYAFET ALBÜMLERİ}

albümlerinin, saray sanatçısı tarafından da üretiliyor olması klyafet albümü piyasasında çarşı ressamları olarak adlandırılan grup yanında saray tarafından desteklenen sanatçıların da etkin olduğunu göstermesi açısından son derece önemlidir. İncelenen albüm resim dili ve açıklamaları ile de kıyafet albüm geleneği içerisinde özgün bir yere sahiptir. Bu çalışma, bir saray nakkaşı olarak Hüseyin İstanbuli tarafından yapıldığı düşünülen bu kıyafet albümlerini inceleyerek literatüre kazandırmayı ve albümlerin Hüseyin İstanbuli tarafından yapıldığı netleştirecek daha somut veriler sunmayı amaçlamaktadır..

Anahtar Kelimeler: Osmanlı resim sanatı, Kıyafet albümü, Hüseyin İstanbuli, XVI. Louis.

\section{A MYSTERIOUS JOURNEY FROM ÍSTANBUL TO PARIS: COSTUME BOOKS, ATTRIBBUTED TO HUSEYIN ISTANBULI}

\section{Abstract}

In this study; It was the 17th century that emerged at the end of the 15th century, which we could describe as painting anthologies offering various cross-sections from Ottoman society. One of the clothing albums, which was generally produced outside the palace, which was widely produced in the 19th century, is examined in the context of Ottoman painting art. Today, the 1688 clothing album, which is found in the Bibliothèque Nationale de France collection in Paris, was prepared by Musavvir Hussein Istanbuli, a member of the Palace nakkas. These albums, which did not have a signature in their paintings, were attributed to him by discussing them comparatively in terms of style and iconography with his paintings in silsilenames, which are now known to him, and the works attributed to him again in the Istanbul Collection of Rare Works. The album was reviewed and Hussein's 17th-century album. It was found that other clothing albums produced in the mid-19th century brought some innovations in stylistic and iconography.

There are 60 paintings in the clothing album that are the subject of the research, and the painting program includes Sultan, Queen-i Azam, other palace officials, men and women from the public, juggling, dervishes and clergy. The fact that clothing albums that are a return to European taste and demand are produced by the palace artist are also very important in terms of showing that the artists supported by the palace are also active in addition to the so-called bazaar painters in the clothing album market. The album, which is examined, has an original place in the tradition of clothing albums with its picture language and descriptions. This work aims to examine these clothing albums, which are thought to have been made by Hüseyin 


\section{İSTANBUL'DAN PARİ'E GIZZMLİ BİR YOLCULUK: HÜSEYİN İSTANBULI'YE ATFEDİLEN KIYAFET ALBÜMLERİ}

Istanbuli as a palace casher, and to provide more concrete data to clarify that the albums were made by Hüseyin Istanbuli..

Keywords: Ottoman painting art, Clothing album, Hüseyin Istanbuli, XVI. Louis

\section{GİRIŞ}

Hüseyin İstanbuli, IV. Mehmet ve II. Süleyman (1678-1691) dönemlerinde sarayda etkin bir nakkaştır. 16. yüzyılda imar faaliyetleri hızla gelişen Edirne, Balkan cephesine olan yakınlığının da etkisi ile 17. yüzyılla birlikte önemini arttırmış padişahlar uzun süreli hatta daimi olarak Edirne sarayında yaşamaya başlamışlardır. Özellikle IV. Mehmet dönemiyle beraber Edirne siyasetin ve sanatın ikinci başkenti olmuştur (Osman, 1989: 21-40). Saray nakkaşları da etkinliklerini Edirne sarayında sürdürmeye başlamıştır. Ancak ne yazık ki Edirne sarayından az sayıda eser günümüze ulaşmıştır (Bağcı vd., 2006: 239). Bu durumun önemli sebepleri arasında, Edirne sarayının 1745 yılında geçirdiği yangın ve 1751 yılında Edirne'de meydana gelen depremle sarayın büyük ölçüde tahrip olması gösterilebilir (Osman, 1989: 21$40)$.

Edirne sarayında görev yapan nakkaş grubu içerisinde Hüseyin İstanbuli de yer almış olmalıdır. İstanbuli'nin IV. Mehmet tasvirleri incelendiğinde IV. Mehmet tasvirlerindeki gerçekçilik ve gözleme dayalı aktarımından padişaha yakın bir nakkaş olduğunu söyleyebiliriz. Bazı eserlerini Musavvir Hüseyin İstanbuli olarak imzalamıştır. Bu imzanın bir amacı Edirne sarayında çalışsa da aslında İstanbullu olduğuna vurgu yapmak istemesinden kaynaklanıyor olmalıdır. Yaşamıyla ilgili detaylı bilgi sahibi olmadığımız Hüseyin İstanbuli imzasını attığı Silsilenameleri ve imzası bulunmasa da diğer eserleriyle üslup özellikleri karşılaştırıldığında kendisine ait olduğunu düşündügümüz kıyafet albümleri ile günümüzde İstanbul Üniversitesi Nadir eserler Kütüphanesinde yer alan bir albüm içerisinde ona ait olabileceğine inandığımız tek yaprak resimleri bulunmaktadır.

İstanbuli'nin 1682 tarihinde hazırladığ AVGM arşivinde 1872 envanter numarası ile kayıtlı Silsilename toplam 20 yapraktan oluşur ve madalyonlar içerisine yerleştirilerek yapılmış toplam 101 resim barındırır, eserin boyutu $172 \mathrm{~mm}$ x $282 \mathrm{~mm}$ 'dir. ${ }^{1}$ Kitap, iki ana bölümden meydana gelmektedir. Birinci bölüm 16 sayfadan oluşan metin bölümüdür (Bayram, 1981: 258). 17. sayfa olan $9 \mathrm{~b}$ varağından itibaren de madalyonlar içerisinde peygamber tasvirleri başlamaktadır. İlk resim Âdem ve Havva'nın tasviridir. Sisilename, IV. Mehmet portresiyle

\footnotetext{
${ }^{1}$ Eserin tıpkıbasımı için bkz: Silsilename. (2000), Genealogical Tree, Ankara, Bayram, Sadi. (1981). Musavvir Hüseyin Tarafindan Minyatürleri yapılan ve halen Vakıflar Genel Müdürlüğ̈̈ Arşivinde muhâfâza edilen silsilenâme.
} 


\section{İSTANBUL'DAN PARİ'E GIZZMLİ BİR YOLCULUK: HÜSEYİN İSTANBULI'YE ATFEDİLEN KIYAFET ALBÜMLERİ}

biter ve padişahın portresinin yanında 'Bende Hüseyin el Musavvir' mühür imzası vardır. (Bayram, 1981: 259). (Resim:1) Bu resimlerinde Hüseyin İstanbuli, figürlerini bir manzara önüne yerleştirerek derinlik etkisi de yakalamıştır (Bayram, 1981: 259). Üslup özellikleriyle özellikle de IV. Mehmet'in duruşu, tahtın topuzunu tutuşu, giysi betimlerindeki zenginlik, kaşların betimlenme biçimi ve firça kullanımı, yüz ifadesindeki doğallık sanatçının kendisini musavvir hakkını işçiliği (Bayram,

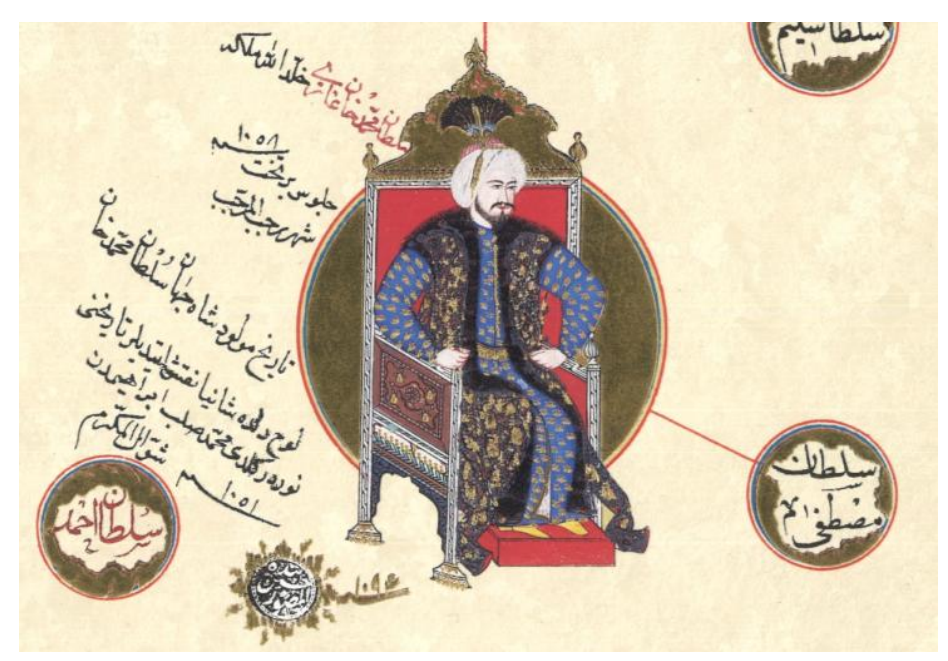
olarak tanitmasinın veren usta bir portre olduğunun kanıtıdır 1981: 259).

Resim 1. Silsilename Vakıflar genel müdürlüğünü arşivinde 1872, y. 20b detay. Musavvir Hüseyin İmzalı IV. Mehmet resmi. Silsilename, Genelogical Tree, 2000.

Hüseyin İstanbuli tarafından yapılan, VÖN'te AF.50 numarası ile kayıtlı Silsilename 18 yapraktan oluşmaktadır ve 30 x $18.1 \mathrm{~cm}$ boyutlarındadır. Eserin, 1b'de unvan tezhibiyle başlayan sayfa ortasında altın yaldızlı kısımda 'Subhatu'l Ahbar' yazmaktadır. ${ }^{2}$ Eserin Merzifonlu Kara Mustafa Paşa vezirliği döneminde Viyana'ya sefere çıkan padişaha sunulmak üzere 1683 yılında tamamlandığı düşünülmektedir (Majer, 1999: 465). Eserin madalyon içerisinde aktarılan peygamber tasvirleri Âdem ve Havva ile başlar. 16a'daki IV. Mehmet tasviri ile sona eren eserde madalyonlar içerisinde toplam 102 tasvir bulunmaktadır. Bu nüshada da IV. Mehmet portresinde tahtın altında 'Amel-i Hüseyin el-Musavvir el- Istanbuli' imzası vardır (Abdurrahim, 2017: 210) (resim:2). Silsilenamelerin Vakıflar örneği ile Viyana örneğinde padişahın tahtta oturuşu ve giysilerin tasvirindeki detayların betimlenişinin bire bir aynı olduğunu söyleyebiliriz ve resimler tasarım açısından da aynı karakteristik özelliklere sahiptir (Majer, 1999: 465).

${ }^{2}$ Eserin iki ayrı tıpkıbasımı için bkz: Subhatu'l Ahbar. (1968) ve Subhatu'l Ahbar (1981). 


\section{İSTANBUL'DAN PARIS'E GIZEMLİ BİR YOLCULUK: HÜSEYIN ISTANBULI'YE ATFEDILLEN KIYAFET ALBÜMLERI}

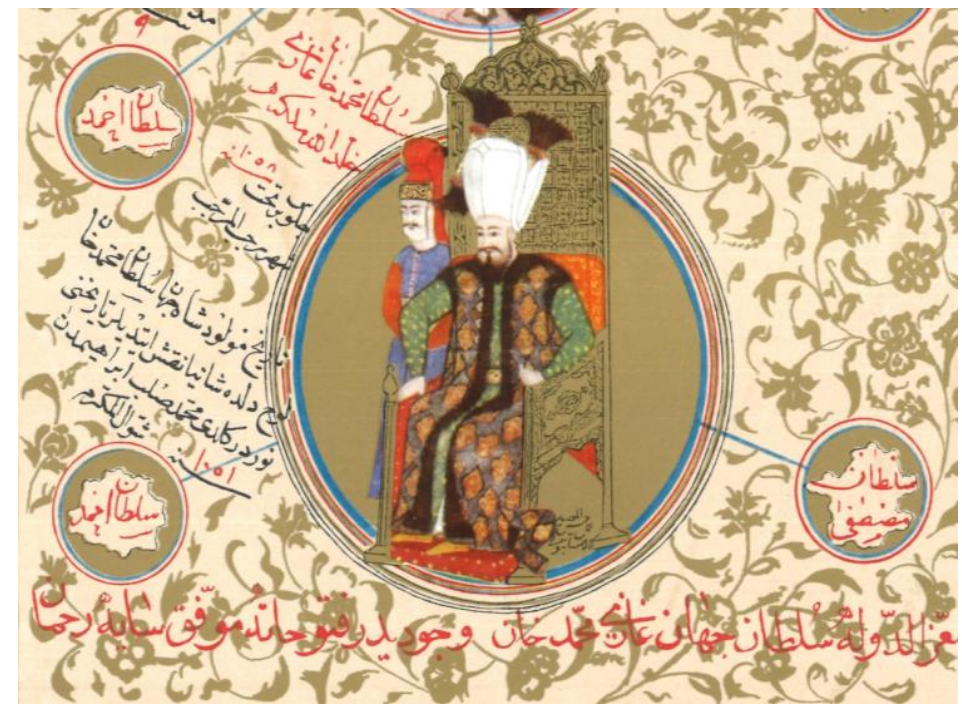

Resim 2. Subhatu'l Ahbar, Viyana Nationalbibliothek'te AF.50, y.16.a detay, Musavvir Hüseyin İmzalı IV. Mehmet. Silsilename. Subhatu'l Ahbar,1968

Sanatçının imzası bulunan Silsilenameleri dışında, İstanbul Üniversitesi Nadir Eserler Kütüphanesinde T.9365 numarası ile kayıtlı albümde de tek yaprak resimleri bulunmaktadır. Albüm içerisindeki 37 resimden IV. Mehmet'in iki yanında silahtarları ile tahtta otururken betimlendiği tasvir ve III. Murat tasviri üslup özellikleri ile Hüseyin İstanbuli'ye atfedilebilir (Bağcı vd., 2006: 242). IV. Mehmet tasviri ikonografik açıdan İstanbuli’nin yaptı̆̆ı diğer portrelerine benzemektedir. Özellikle de taht betimleri hemen hemen aynıdır (Bağcı vd., 2006: 242). Ancak Hüseyin İstanbuli tarafından yapılan diğer IV. Mehmet tasvirleri incelendiğinde T.9365 numaralı albüm içerisinde bulunan IV. Mehmet tasviriyle yüz hatları benzememektedir.

$\mathrm{Bu}$ tasvirde padişahın yüzü daha sivri, gözleri daha yuvarlak ve özellikle yüzü yorgun, sanki hastalıklı olarak betimlenmiştir, kırışıklarının sayısı da daha fazladır, gözler dalgın bir ifade verilmiştir. IV. Mehmet'in diğer tasvirlerinde yüzünde bu kadar melankolik bir ifade yoktur, daha dinç ve genç görünmektedir (Resim:3,4 ). Albümde bulunan bir diğer tasvir üzerinde 'Düğün sahibi Murat-1 salih' yazmaktadır. Albüme seçilen resimlerin neye göre veya ne için seçildiğini ve İstanbuli’ye atfedilen bu tek yaprak resimlerin albüme eklenmesinin özel bir sebebi olup olmadığı sorularına kesin olarak yanıt bulmak oldukça güçtür. Ancak albümde tasvirlerin yapıştırıldığı kâğıtlardaki işçilik de göz önüne alındığında bir vassal tarafından padişah veya üst düzey bir devlet adamı için derlendiği düşünülebilir. 


\section{ISTANBUL'DAN PARIIS'E GIZEMLİ BİR YOLCULUK: HÜSEYIN \\ ISTANBULI'YE ATFEDILLEN KIYAFET ALBÜMLERI}

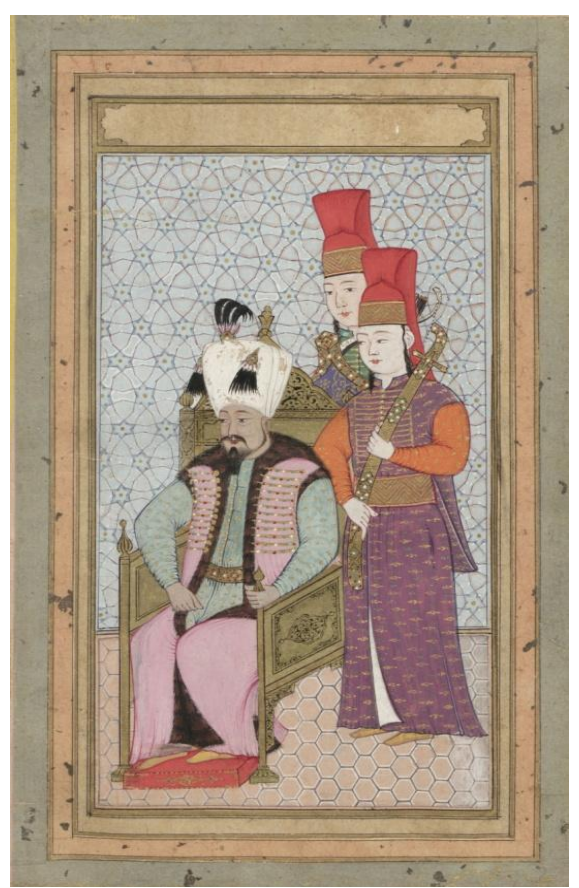

Resim 3. İstanbul Üniversitesi Nadir Eserler Kütüphanesi, T.9365, IV. Mehmet tasviri. 19b.

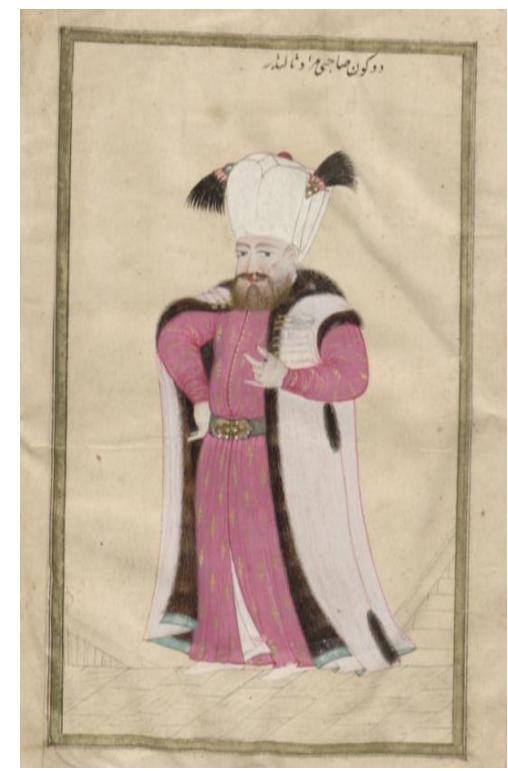

Resim 4. İstanbul Üniversitesi Nadir Eserler Kütüphanesi, T.9365, III. Murad Tasviri.

\section{Hüseyin İstanbuli’ye Atfedilen Kıyafet Albümleri}

Tek veya grup halinde figür resimlerinin bulunduğu albümler (murakkalar) Osmanlı kültüründe 15.ve 16. yüzyıllardan itibaren görülmeye başlamış, 17. yüzyılda yaygınlaşarak devam etmiştir. ${ }^{3}$ Albümler, içerdikleri resimlerin bir metne bağlı olmamasıyla el yazma kitaplardan ayrılırlar. Albümler içersinde hat, tezhip ve kâğıt oyma örneklerinin yanı sıra tek yaprak resimler de bulunmaktadır. Osmanlı sarayında tek figür betimlerden oluşan albüm

\footnotetext{
${ }^{3}$ Murakka: Hazırlandığı dönemin ve geçmişin ünlü hattatlarının, musavvir ve müzehhiplerinin, kağıt oyma sanatçılarının tek yapraklar halinde olan çalışmalarını bir cilt içinde toplayan bir tür kitaptır.
} 


\section{İSTANBUL'DAN PARİ'E GIZZMLİ BİR YOLCULUK: HÜSEYİN İSTANBULI'YY ATFEDILEN KIYAFET ALBÜMLERİ}

yapımı I. Ahmet (1603-1617) döneminden itibaren yaygınlaşmıştır. 17. yüzyıl başlarında vassal ${ }^{4}$ Kalender'in I. Ahmet için hazırladığı iki murakka ve bir falname bulunmaktadır. Murakkalardan biri güzel yazı örneklerinden oluşmaktadır (İnal,1984: 83).

İkinci albümde ise yine güzel yazı örnekleri ile birlikte farklı ellerden çıkmış büyüklü küçüklü, saraydan eğlence sahneleri ile saray dışından günlük yaşam sahneleri, devlet adamları ve halk arasından farklı kıyafetlerle kadın ve erkek figürler ve hamam sahneleri betimlenmiştir. I. Ahmet Albümü diye de anılan bu murakka yüzyıl içerisinde hazırlanan diğer bu tür albümlerinde öncüsü sayılmıştır (Bağc1 vd., 2006: 230). Bu albümün içerisinde çok sayıda kıyafetin ön plana çıktığı tek figür resimler bulunmaktadır (Renda, 1998:160).

Osmanlı toplumu, 15. yüzyıldan beri Avrupalıların ilgisini çekmiştir. 16. yüzyıldan sonra giderek gelişen siyasi ve ticari ilişkilerin etkisiyle beraber de birçok Avrupalı diplomat, gezgin ve tüccar Osmanlı topraklarına gelmiştir. Bu kişilerin bazıları anılarını yazarak Osmanlı kıyafetlerini tanıtan resimler de ekleyerek bunları yayınlamıştır (Schick,2003: 84). 16. yüzyıldan başlayarak 17. yüzyılda yaygınlaşan bu gelenek genellikle saray dışında üretilmiş olan klyafet albümleridir. Kıyafet Albümlerini, genel olarak Osmanlı toplumundan çeşitli kesitleri sunan resim antolojileri olarak tanımlayabiliriz (Schick, 2003: 84). Bu albümler, daha çok çeşitli amaçlarla Osmanlı topraklarına gelen Avrupalılara verilmek veya satılmak üzere hazırlanmışlardır (Renda 2009: 1120). Osmanlı kıyafet albümleri, bireyin kimliğini, politik, sosyal ve diplomatik gibi statülerini belgelemek için daha çok kıyafetlerin ön planda tutulduğu albümlerdir. Albüm içerisindeki figürlerin, kıyafet ve aksesuarları statü ve görevlerine gönderme yapmaktadır. Bireyin kimliği tanımlamak için çevre ve kıyafet betimlemelerine başvurulması metodunun kökeni MÖ. 5. yüzyıl tarihçisi Herodot'a kadar inmektedir. Herodot'un Tarihler adlı eserinde bahsettiği insan topluluklarını birbirinden ayırmak için, toplumları evrensel olarak tanımladığı yedi farklı kültürel kategori içinde analiz ederek, dil, beslenme alışkanlıkları, yerleşim, savunma yöntemleri, diğer toplumlar arasındaki yerleri, doğal çevre ve giyinme biçimleri alt başlıklarına başvurması kıyafetlerin kültür içindeki yerinin önemini göstermektedir (Schick, 2003: 86).

Kıyafetlerin kumaşı, tarzı, rengi ve modası onları giyenlerin kimliği ile belirlenmekteydi. Kıyafetler, toplumsal, mesleki, etnik ve siyasal kimliği temsil etmektedir. Bu durum sadece Osmanlı toplumu için değil Avrupa toplumu içinde de aynı şekilde devam etmekteydi. Leslie Schick'in aktarımıyla, İngiltere'de, Lancaster kontunun bir yıl boyunca dağıttığı kumaşların renkleri rütbelere göre ayrılmaktaydı. Kont kendisine kırmızı, piskoposa koyu kırmızı,

\footnotetext{
${ }^{4}$ Vassal: Murakkalara yapıştırılan kâğıtları yeri belli olmayacak şekilde kaynaştıran ustalara denmektedir. Kalenderin yazdığı güzel yazı albümü Topkapı Müzesi koleksiyonundadır; TSM, H2171
} 


\section{İSTANBUL'DAN PARİ'E GIZZEMLİ BİR YOLCULUK: HÜSEYİN İSTANBULI'YY ATFEDILEN KIYAFET ALBÜMLERİ}

şövalyelere mavi renkli kumaş hediye ederken ağartılmış keten kumaşlar da kont ve papazlar içindi (Schneider, 2000: 114). Osmanlı toplumunda ise bu durumun belirleyicisi daha çok 'dini inanç’ olmuştur. Örneğin ayakkabılar, Müslümanlar için sarı renkli, Rumlar için kırmızı, Yahudiler için ise mor renkliydi (Anonim, 2014: 34). Kıyafet albümü derleyicileri bu kolay okunabilen kıyafet kalıplarına özellikle sadık kalmışlardır. 1614 yılında İstanbul'da bulunan Seyyah Pietro della Valle bir mektubunda, 'Bu şehrin hem erkek, hem kadınlarının her türlü giysilerinin canlı modelden yapılmış çizimlerinden oluşacak bir kitap sipariş ettiğini" söyler (Aktaran: Schick, 2003: 86, : Vella, 1989: 14).

Bu kıyafet albümlerinin üretimini 16. yüzyıldan beri saray dışında etkinliklerini sürdüren ressamlara bağlayabiliriz. Saray dışında etkinliğini sürdüren bu nakkaşlar atölyelerinde İstanbul'a gelen yabancılar için tek figür resimler ve kıyafet albümleri hazırlamışlardır. Metin And, saray dışında ticari yapılarda, atölyelerde üretim yapan, daha çok albüm ve tek yaprak eserler hazırlayanlar için Çarşı Ressamları sıfatını kullanmıştır (And, 1985: 40-45, And, 1990: 5-11, And, 2019: 45). Yukarıda da değinildiği gibi, Evliya Çelebi de Seyahatnamesi’nde İstanbul'daki esnaf grupları arasında, müzehhip, mücellid ve nakkaşlar olduğunu belirtir ve bu nakkaşları üç ana grupta toplar (Dağl1, 2003: 48). İlk grup, Arslanhane'nin üst katlarındaki hücreler ve yüz dükkânda çalışan esnaf-1 nakkaşan-1 cihan ile evlerinde çalışan bin nefer saray-1 ali nakkaşlarından oluşur. İkinci grup ise daha çok kahramanlık ve mücadele sahneleri içeren şehname tasvirleri yapan kırk nefer esnaf-1 nakkaşan-1 musavvir'dir. Üçüncü grup ise Peygamberler ve Padişahlar hakkında halk arasında yaşatılan hikâyeleri, aşk öykülerini betimleyen ve tasvirler eşliğinde fal söyleyen ve Mahmut Paşa Çarşısı'nda bir dükkânda bulunan bir nefer esnaf-1 Falcıyan-1 musavvirdir (Mahir, 2005: 73). İstanbul'da albüm resimleyen bu atölyelerde seri halde üretilen resimler alıcıya göre İtalyanca, Fransızca ve İngilizce açıklamalar eklenerek çok büyük olasılıkla albüm haline getirilmiştir. Bu albümlerin bazıları elçilik heyetleri ile birlikte gelen yabancı ressamlar tarafından yapılmışsa da özellikle 17. yüzyıldan itibaren yerli sanatçılar tarafından da üretilen çok sayıda albüm bulunmaktadır (Renda,1977: 45).

Kıyafet Albümlerinde genellikle figürler boş bir zemin üzerine yerleştirilerek statülerine göre giyinmiş halde ve bazen bir işle meşgul olurken aktarılırlar. Sayfanın alt veya üst kısmında bazen bir bazen de birkaç farklı dilde kısa açıklamalar bulunmaktadır. Kıyafet Albümleri genellikle yapıldığı dönemde hüküm süren Osmanlı Padişahının resmi ile başlar ve arkasından devletin ileri gelenlerinin resimleri ile devam etmektedir. Sokak satıcıları, köleler, hanım Sultanlar, cariyeler, deliler, dervişler gibi pek çok konuyu barındıran bu albümler zengin bir resim repertuarına sahiptir (Küçükhasköylü, 2010: 40). 


\section{İSTANBUL'DAN PARİ'E GIZZEMLİ BİR YOLCULUK: HÜSEYİN İSTANBULI'YY ATFEDILEN KIYAFET ALBÜMLERİ}

Albümlerin alıcısını Osmanlı dünyası ile ilgili pek çok konuda bilgi sahibi yaptığını ve Avrupa'da oluşan Türk akımının moda kataloğu görevini üstlenmiş olduğunu öne sürebiliriz (Oruç, 2017a:38). Mozart tarafından, Topkapı Sarayı'nı konu edinen "Saraydan Kız Kaçırma” operasının yazılmasını ve Osmanlı temalı tiyatro oyunlarının hazırlanmasını bu kıyafet albümleri ile ilişkilendiren araştırmacılar mevcuttur (Oruç, 2017a:38). Pek çok dilde ve ülkede basılan Kıyafet Albümleri Avrupa pazarı için her dönem popülaritesini korumuştur. Kıyafet Albümleri sadece bir giysi koleksiyonu olmanın çok ötesinde bütün bir halkın, bütün bir kültürün Avrupalı okur kitlesi için çözümlenmiş, düzenlenmiş ve özetlenmiş bir kitaba sığdırılmış Osmanlı dünyasının portresidir. Bu albümler bir toplumu dolaşmak için kullanılacak rehberler olmuşlardır (Oruç, 2017a:40). Avrupa toplumunun bu ilgisi o kadar çok artmış ki, zamanla kıyafet albümlerinden tek yaprak resimler tek halde satılmaya başlamış hatta porselen eşyaların, fayansların ve çeşitli duvar panolarının üzerlerini bezemişlerdir (Oruç, 2017b: 99).

17. yüzyıl sonunda Hüseyin İstanbuli’nin resmettiği düşünülen iki kıyafet albümü Paris Bibliothèque Nationale de France koleksiyonunda N.Od.7 ve N. Od. 6 numaraları ile kayıtlıdır. ${ }^{5}$ Albümlerden 1688 tarihli (N.Od.7 ) olan örnek çalışmanın ana konusu olarak seçilmiştir. Bunun en önemli nedenlerinden biri Süheyl Ünver'in N. Od. 6 numaralı albüm üzerine çalışıp resimlerin çevirileriyle birlikte kataloglayıp yayımlamış olmasıdır. Bir diğer sebep ise, N.Od.6 numaralı albümün 1720 tarihli olması ve bu albümün 1688 tarihli albümden bakılarak kopya edildiğinin düşünülmesidir.

Çalışma konusunu oluşturan N. Od.7 numaralı ana albümün, Fransız diplomat Pierre de Girardin'in 1686-1688 yılları arasında İstanbul'da kaldığı zaman içerisinde XIV. Louis'e (16431715) II. Süleyman'1 (1687-1691) haremini, sarayını ve Osmanlı devletini tanıtmak için sipariş edip XIV. Louis'e hediye etmiş olabileceği düşünülmektedir. Albümde sipariş süreciyle ilgili herhangi bir kayıt bulunmamaktadır. Ancak elimizdeki veriler değerlendirildiğinde albümü sipariş eden kişinin XVI. Louis olabileceği bile söylenebilir. XVI. Louis'in duyduğu Türk hayranlığına örnek olarak, 1669 yılında Osmanlı Devleti tarafından Fransa'ya gönderilen heyetin başında bulunan Süleyman Müteferrika için bir karşılama töreni hazırlatması ve bu tören için özel 'elmaslarla kaplı’ bir kıyafet giymesi gösterilebilir (Wılliams, 2014: 32). Bu karşılama töreni daha sonra Jean Le Pautre tarafindan çizilmiştir (resim:5).

\footnotetext{
${ }^{5}$ Söz konusu kıyafet Albümünün (Od.6) siyah beyaz basımı Sühely Ünver (1958) tarafından yapılmıştır. 


\section{İSTANBUL'DAN PARIS'E GIZEMLİ BİR YOLCULUK: HÜSEYIN ISTANBULI'YE ATFEDILLEN KIYAFET ALBÜMLERI}

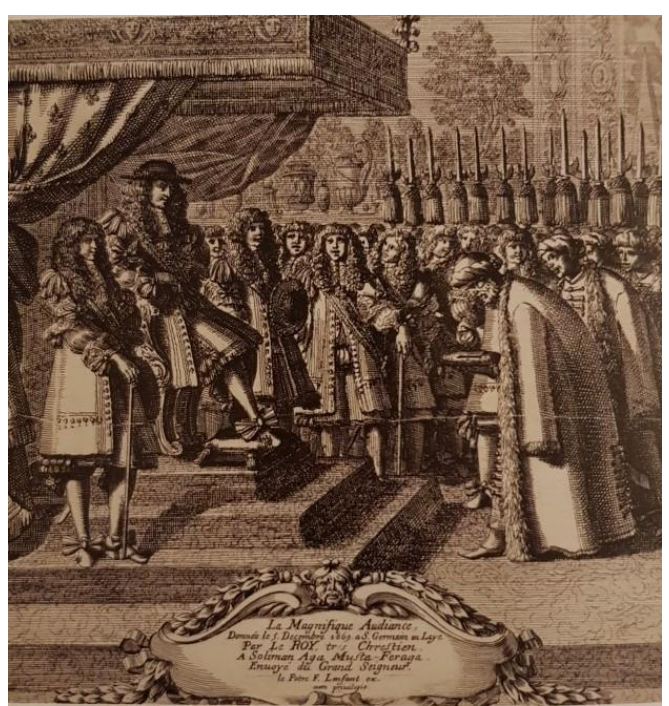

Resim 5. Jean Le Pautre, 1669, XVI. Louis'in Süleyman Ağa Müteferrika'yı karşılama töreni, Wıılliams, Haydn, s.3

XVI. Louis bu karşılama töreninin bir oyuna dönüştürülmesini de istemiş ve bu şekilde Moliere'in 'Kibarlık Budalası' adlı comedie-ballet'i ortaya çıkmıştır. Oyun ilk kez 1670'te Chambord Şatoşu'nda sahneye konulmuştur (W1lliams, 2014: 35). Oyunun kostümleri için titizlikle çalışılmış, kostümler Doğu Akdeniz'i dolaşmış ve elçilik tercümanlığı yapmış Şövalye Laurent d'Arvieux'nün tavsiyeleri ile Henri Gissey tarafindan tasarlanmıştır. Arvieux anılarında, Türk tarzı kıyafetler ve sarıklar için dönemin usta terzisi Baraillon'la beraber sekiz gün çalıştığını aktarmaktadı (Wı1liams, 2014: 78). Oyunun kostümleri için bu kadar hazırlık yapılması Türk akımının dönem içinde ne kadar önemli olduğunu ve Kral'ın Osmanlı toplum ve giyimine duyduğu ilginin önemli bir kanıtı olarak son derece önemlidir.

Süleyman Ağa'nın ziyaretinin elçilik heyetlerinin gittikleri toplumun kültürlerini nasıl etkilediğini gösteren önemli bir yan ise, kahve içme alışkanlığının Süleyman Ağa'nın Paris'e gidişiyle beraber yerleşmesidir. 1672'de Saint- Germain'de Paris'in ilk kahvehanesi açılmıştır (Wılliams, 2014: 35). Kahve ve Osmanlı kültürü Paris'te o kadar benimsenmiş ki, 1685 yılında yayımlanan Philippe- Sylvestre Dufour'un kitabının ön sayfasında yer alan resimde elinde kahve fincanıyla bir Türk görünmektedir (resim:6). Ayrıca ressamının adı bilinmeyen ama Alman asıllı olduğu bilenen bir sanatçı tarafından 1700' lü yıllarda XVI. Louis doğu etkisiyle harmanlanmış kıyafetler içerisinde resmedilmiştir (resim:7) (Wılliams, 2014: 32). Bu resmin tarihinin çalışma konusunu oluşturan 1688 tarihli kıyafet albümünden sonra yapılması XVI. Louis'in bu kıyafet albümünden haberdar olduğu konusunda heyecan veren bir ipucu olarak değerlendirilebilir.

XVI. Louis resimde tipik Osmanlı kaftanı ve sarığıyla, şalvar, iç entari ve iç kaftandan oluşan Osmanlı dokuma kumaşları içersindeki tasvir edilmiştir. Özellikle Padişah tasvirlerinde 


\section{İSTANBUL'DAN PARİ'E GIZZEMLİ BİR YOLCULUK: HÜSEYİN İSTANBULI'YE ATFEDILEN KIYAFET ALBÜMLERİ}

sıkça karşımıza çıkan sarı renkli ayakkabılarında seçilerek ikonografiye eklenmesi bu savımızı destekler niteliktedir. XVI. Louis'in Osmanlı toplumuna duyduğu ilginin tüm bu sonuçları göz önüne alınırsa söz konusu kıyafet albümünü, Pierre de Girardin'den kendisi bizzat istemişte olabilir. XVI. Louis'in doğu kıyafetleri içerisindeki resmini de göz önüne alırsak albümü görüp incelediği varsayımında bulunabiliriz. Belki de Girardin, Kral tarafından bizzat sipariş edilen bu kıyafet albümü hazırlama işi için usta bir ressam aramış ve teknik bilgisi kuvvetli, çarşı atölyelerinde de bireysel işler üreten, saray halkını da yakından tanımasıyla meşhur, bir saray nakkaşı olan Musavvir Hüseyin İstanbuli’ye yönelmişti.

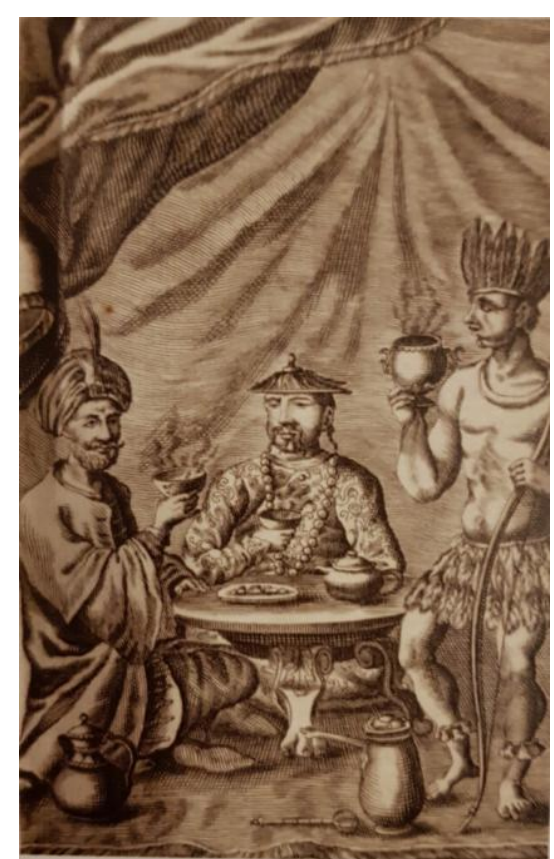

Resim 6. Philippe- Sylvestre Dufour, 1685, kahve, çay ve çikolata, Wılliams, Haydn, s.35

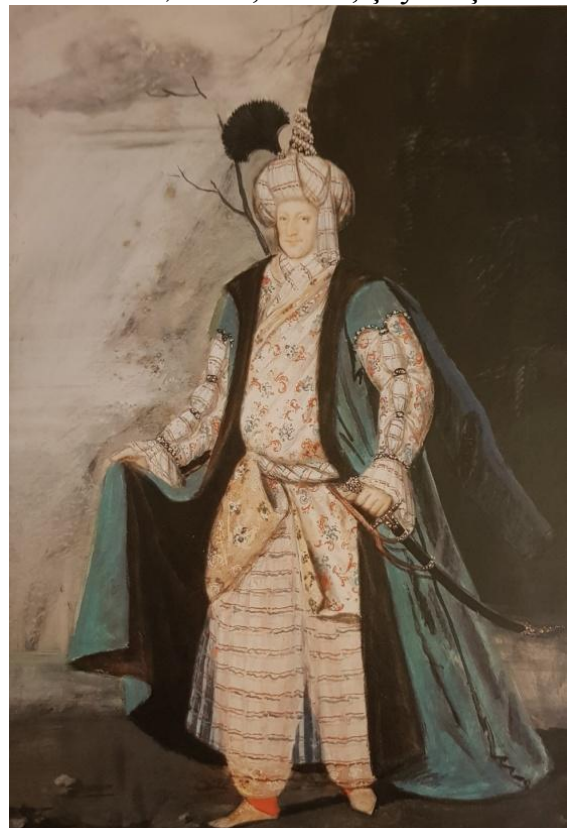

Resim 7. Bilinmeyen Alman sanatçı, 1700’lü yılların başı, XVI. Louis, Wı1liams, Haydn, s.33. 


\section{İSTANBUL'DAN PARIS'E GIZEMLİ BİR YOLCULUK: HÜSEYIN ISTANBULI'YY ATFEDİLEN KIYAFET ALBÜMLERİ}

N. Od. 7 numaralı 1688 tarihli albüm 60 resim içerir ve boyutu yaklaşı olarak $25.3 \mathrm{~cm}$ x 12. 5 cm'dir (Versailles, 1999: 113). Resimlerin bir ön sayfasında veya bir arka sayfasında tasvirle ilgili, statüsünü belirten veya görev tanımını içeren Fransızca açıklamalar bulunmaktadır. Albüm resim programı içerisinde, II. Süleyman, sadrazam, kazasker, müftü, diğer saray görevlileri, Haseki Sultan, hokkabazlar, genç kadın (resim:8,9) ve erkek tasvirleri, aşçı, mandıracı, sebilci, berber gibi çeşitli meslek gruplarının tasvirleri, farklı mezheplere mensup din adamları ve Mevlevi, Bektaşi, Gülşeni, Özbek ve seyyah dervişler yer almaktadır. 60 resmin 11'i derviş tasvirlerine ayrılmıştır. Kıyafet albümlerinde fazla sayıda derviş tasvirinin yer alması durumu ilk değildir, Manchester kıyafet albümü içerisinde de 17 derviş tasviri vardır. $\mathrm{Bu}$ durum derviş giyimlerinin kendine özgü standart dışı, etnik ve çok renkli olması sebebiyle dikkat çekmesine bağlanabilir. Osmanlı toplumundan pek çok kesimden örnek teşkil etmesi açısından bilinçli olarak bu şekilde sipariş edilmiş olmalıdır.

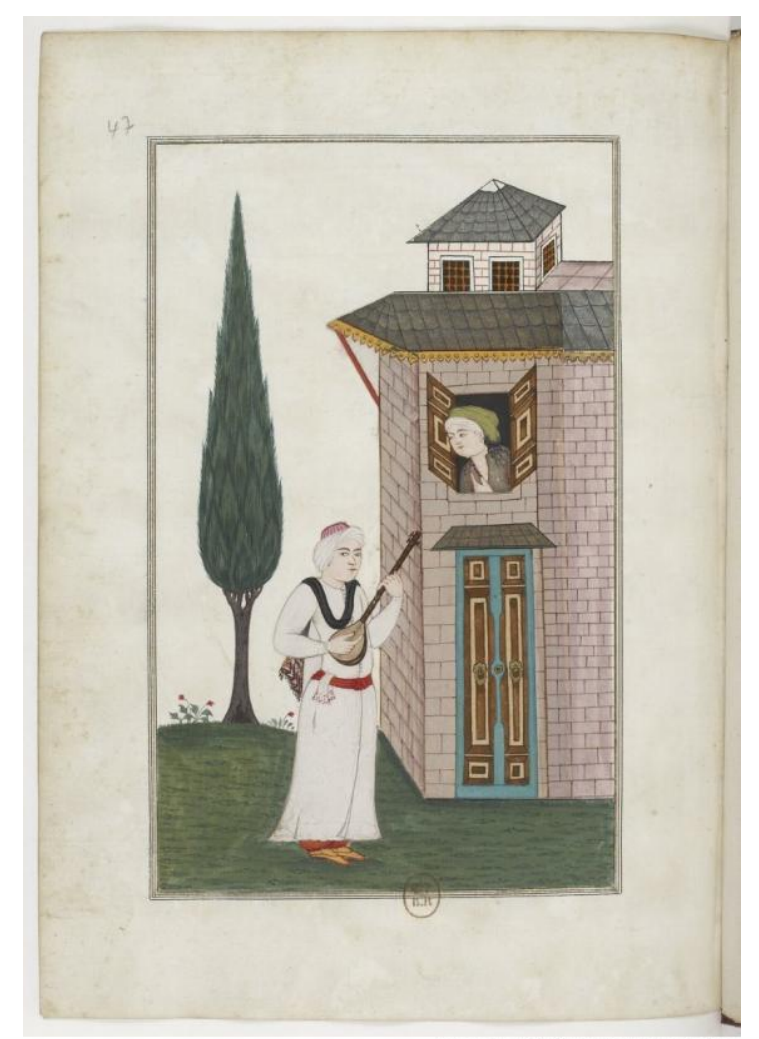

Resim 8. Paris Bibliothèque Nationale de France, N.Od.7, 47.y.47a.

47.y. 47b, imgenin açıklaması:

'Un bomme qui joe du Jamboura v qui parle a sa Maitresse.'

Tambur çalıp karısı ile (hanım efendi) ile konuşan bir adam. 


\section{İSTANBUL'DAN PARIS'E GIZEMLİ BİR YOLCULUK: HÜSEYIN \\ ISTANBULI'YE ATFEDILLEN KIYAFET ALBÜMLERI}

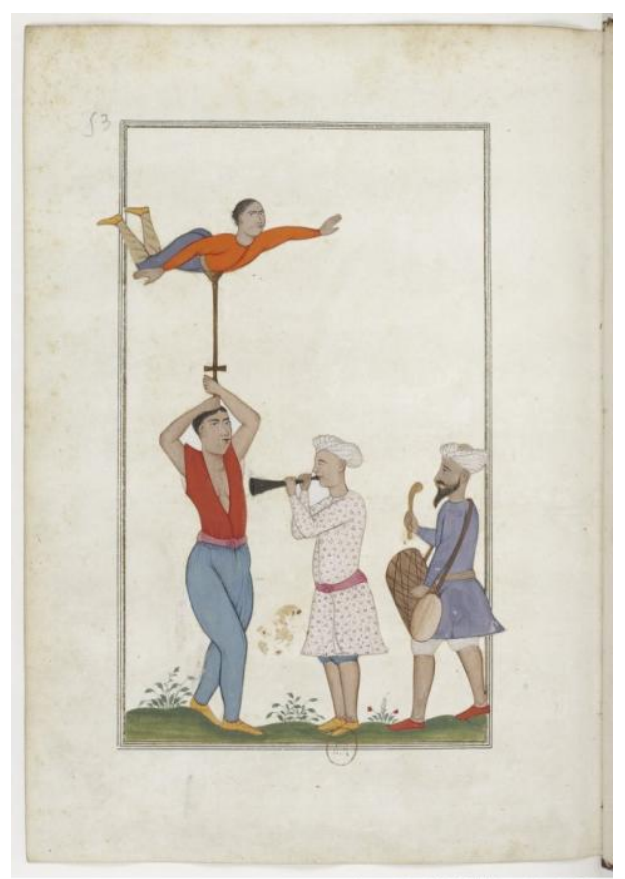

Resim 9. Paris Bibliothèque Nationale de France, N.Od.7, 53.y.53a, Sauteurs des Indes, Hintli cambazlar, 53.y.53b, imgenin açıklaması:

'Sauteurs des Indes, qui servent au divertissement du Grand Seigneur.'

Hintli cambazlar, padişahın eğlencesinden sorumludurlar

N. Od. 6 numaralı albüm içerisinde ise 49 resim bulunmaktadır. Bu albüm de yaklaşık olarak diğer albümle aynı boyutlardadır. 1720 tarihli albümün, XV. Louis'e (1715-1774) sunulmuş olduğu düşünülür çünkü albüm, XV. Louis kitaplığında yer almaktadır (Majer, 2000: 344). Bu albümde diğerine göre daha az açıklama yer almaktadır. Tasvirlerin üstünde Osmanlıca ve Fransızca kısa açıklamalar bulunmaktadır. Fransız elçisinin İstanbul'da bulunduğu süre içerisinde iki albümü de sipariş edip yanında götürdüğü ama iki farklı tarihte iki farklı krala sunmuş olabileceği gibi, (Majer, 2000: 344) 1688 tarihli albümün ilgi çekmesi sonucu bu albümden bir kopya yapılması istenmişte olabilir. Albümler Fransız kraliyet kütüphanesi (Bibliotheque Royale) koleksiyonuna eklenmiştir. Albüm resim programı içerisinde, II. Süleyman, sadrazam, kazasker, müftü, diğer saray görevlileri, genç kadın ve erkek tasvirleri, farklı mezheplere mensup din adamları, Mevlevi ve Bektaşi dervişleri, saka, bandıracı, hamal, aşçı gibi farklı meslek gruplarından figürler ve son sayfa da Süleymaniye Cami'nin tasviri yer almaktadır.

Süheyl Ünver, bu tasvirin koleksiyonda Ayasofya Cami olarak kayıtlı olduğunu kendisinin bu yanlışlığı gidererek Süleymaniye Cami olarak düzelttiğini aktarır, kendi çalışmasında da görsel künyesinde Süleymaniye Cami olarak aktarmıştır. Bu nüshada derviş tasvirlerinin sayısı 2'ye düşmüştür. Ancak kadın tasvirleri sayısı artmış ve çeşitlenmiştir. Haseki Sultan tasvirinin dışında, nakış işleyen, öreke işleyen, çocuğu ile yolda yürüyen, eşi-çocuğu ile birlikte bir yere giden, müzisyenler, Müslüman, Yahudi ve Rum kadınları bulunmaktadır. Rum 


\section{İSTANBUL'DAN PARİ'E GIZZMLİ BİR YOLCULUK: HÜSEYİN \\ İSTANBULI'YE ATFEDİLEN KIYAFET ALBÜMLERİ}

kadının elinde şarap kadehi ve şarap testisi bulunmaktadır. Bu durumu sanatçının bu albümü Avrupalı bir alıcı için yaptığına kanıt olarak gösterebiliriz. İkonografik öğe seçimlerinde özgür bırakıldığını düşünebiliriz. İki albümde de Haseki Sultan tasvirlerinde sultan kahve içmektedir. $\mathrm{Bu}$ ikonografi de bilinçli bir tercih veya istek doğrultusunda yapılmış olabilir. İstanbuli'nin kıyafet albümleri içerisinde ki kadınların Avrupalı alıcının isteği doğrultusunda çekici ve dişi özellikleri ön planda tutularak yapıldığı öne sürülmektedir (Majer, 2000: 463). Fransa kralının kadınlara karşı duyduğu ilgi albüm resimlerindeki kadın figürlerin (Resim:10) daha canlı ve çekici yapılmasını sağlamış olabilir (Majer, 2000: 345).

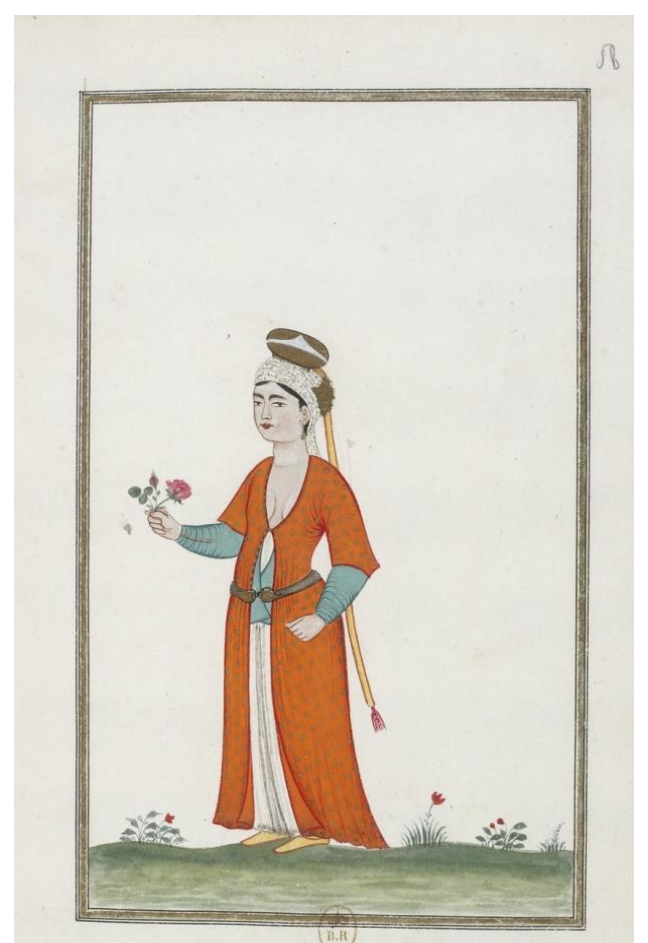

Resim 10. Paris Bibliothèque Nationale de France, N.Od.7, Yahudi Kadın.

İmzasız olan iki albümde de II. Süleyman tasvirlerinde tahtın modeli ve tahtın duruşu, II. Süleyman'ın tahtın topuzunu tutuşu, detay gerçekçiliği ile yapılmış giysi betimleri, figürlerin yüz ifadesi ile içinde bulunduğu ruh halini hissettirebildiği özgün tekniği, sakal ve kaş betimlerindeki fırça darbeleri Silsilenameler içerisinde imzalı olan Hüseyin İstanbuli tasvirleriyle kıyaslandığında ortaktır (Majer, 2000: 345). Ayrıca iki albümde de II. Süleyman tasvirlerinde tahtın arkasında duran muhafız betimlemeleri de birbirlerinin aynısıdır. Yüz hatları, kaş, göz ve bıyık betimleriyle bakıldığında aynı kişiler olduğu düşünülmektedir.

$\mathrm{Bu}$ durum Hüseyin İstanbuli'nin albüm resimlerini birbirinden kopya ederek çoğaltmasının mı yoksa belli görevdeki kişiler için aynı tipi kullanmayı tercih etmesinden mi kaynaklanmaktadır net olarak söylemek güç olsa da albümlerin birbirlerinden kopya edilerek çoğaltıldığı savının daha güçlü bir kanıtıdır. Aynı statüdeki figürlerin birbirinin aynı olarak iki 


\section{İSTANBUL'DAN PARİ'E GIZZEMLİ BİR YOLCULUK: HÜSEYİN \\ İSTANBULI'YE ATFEDİLEN KIYAFET ALBÜMLERİ}

albümde yer alması durumu, özellikle İç oğlanlar, Şahinci başı, saray ağası, yelpaze taşıyan görevli ve kırmızı feraceli kadın figürlerinde daha yoğun hissedilmektedir. Bu betimlerin sadece giysi renkleri ve figürlerin duruşları değil yüz hatları, kaş, göz betimlemeleri de birebir aynıdır (Resim:11,12). Her iki albümde de figürler, albüm içerisinde yer alan görev tanımlarına işaret eden objelerle birlikte tasvir edilmiştir.

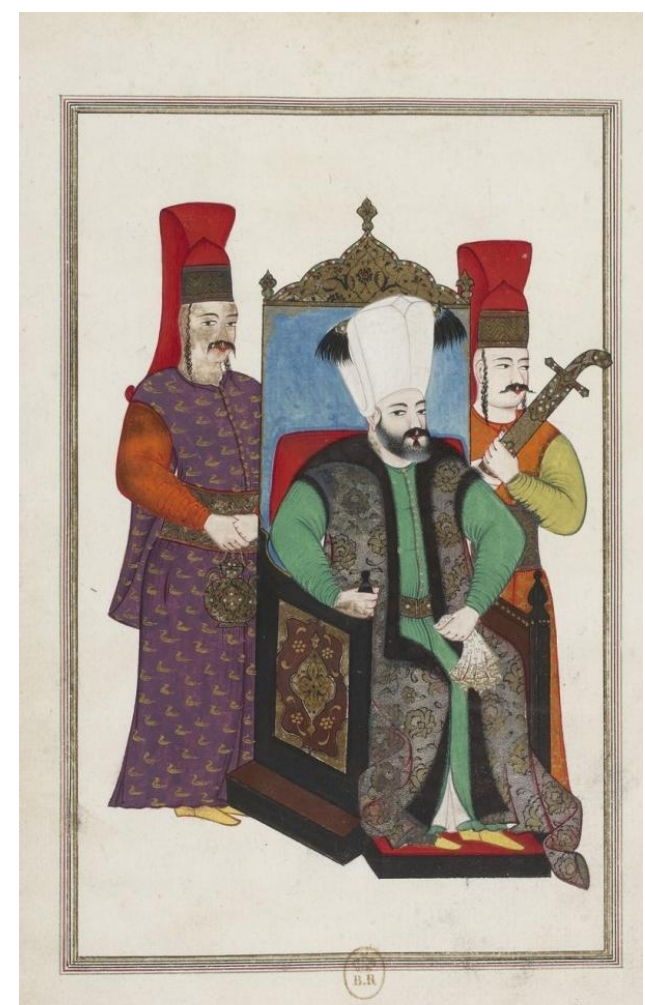

Resim 11. Paris Bibliothèque Nationale de France, N.Od.7, 1.y.1a, Le Grand Seigneur Sultan Soliman III, II. Süleyman. 


\section{İSTANBUL'DAN PARİ'E GIZZEMLİ BİR YOLCULUK: HÜSEYİN ISTANBULI'YY ATFEDİLEN KIYAFET ALBÜMLERİ}

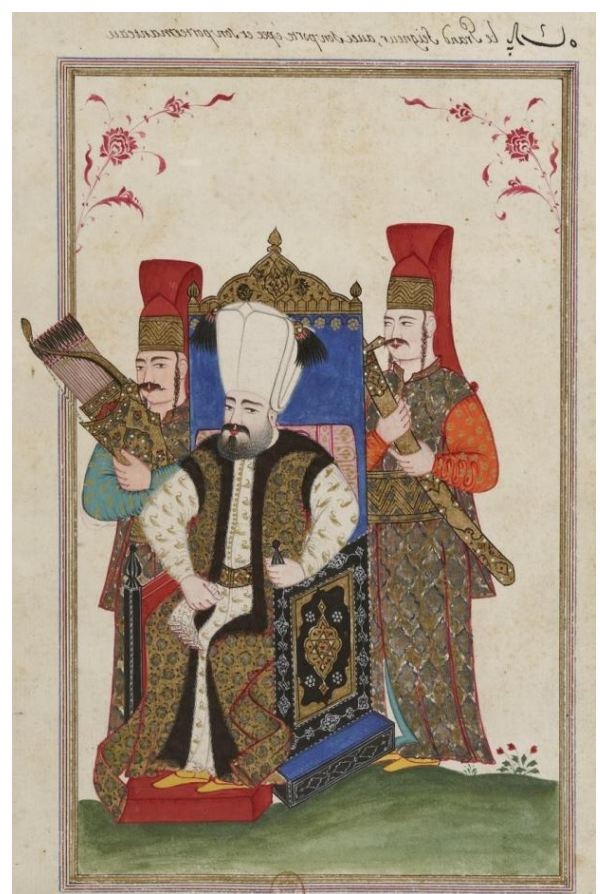

Resim 12. Paris Bibliothèque Nationale de France, N.Od.6, 1.y, Le Grand Siegneur, avec son propre epee et son porte manteau.

1688 tarihli N.Od.7 numaralı albüm III. Süleyman'ın tasviri ile başlamaktadır. Tasvirin arka sayfasında Fransızca açıklama yer almaktadır. Fransızca açıklamanın Türkçe transkriptasiyonu şu şekildedir;

1.y.1b, imgenin açıklaması:

"Le Grand Seigneur Sultan Soliman III. a present regnant. Il portre ses aigrettes basses au Turban, parce qu'il n'a pas fait encore de conqueste, les Empereurs Turcs ne pouvant les porter bautes bautes qu'apres avoir pris qelque ville ou province. A sa gauche le Sclictar, ou celuy qui porte son sabre; c'est le Chef des quatre Odas ou chambres des Itchoglans, ou Pages du Serail. A la droite du Grand Seigneur est l'Ibrictar, ou celuy qui porte l'eau dont il peut avoir besain soit pour boire, soit pour se laver avant de faire sa prieres."

'Şu andaki Hükümdar III. Süleyman, Türbanının altında kuş tüyü var, çünkü henüz bir fetih yapmadı. Bir şehir ya da bölgeyi almadan tüyü yukarıda taşlyamıyor. Solunda silahtar var, sabre (kılıç) taşılyor. Silahtar, aynı zamanda iç oğlanların veya 4 odanın başı, Sağında ibriktar var. Su taşlyor ve abdestinde yardim ediyor ${ }^{\circ 6}$ (Resim:11).

Kıyafet albümünün ilk resminde, Sultan II. Süleyman tahtta otururken, sağında ve solunda silahtar ve ibriktarla beraber tasvir edilmiştir. Kıyafet albümünde III. Süleyman diye

\footnotetext{
${ }^{6}$ Silahtar: Padişahın güvenliğinden sorumlu en kidemli görevli.

İbrikçi: Padișahın temizliğinden sorumlu olan görevli.

*Fransızca çeviriler: Değerli arkadaşım Mütercim Tercüman Celal Demiröz tarafından yapılmıştır.
} 


\section{İSTANBUL'DAN PARİ'E GIZZEMLİ BİR YOLCULUK: HÜSEYİN İSTANBULI'YE ATFEDİLEN KIYAFET ALBÜMLERİ}

bahsedilse de aslında bahsedilen II. Süleyman'dır (1687-1691). Yıldırım Beyazıt (1360-1403) zamanında yapılan Ankara savaşında Timurlulara yenilmesi üzerine 1402-1413 yılları arasında yaşanan fetret devrinde, Osmanlı toprakları Yıldırım Beyazıt'ın beş oğlu arasında pay edilmişti. Bu paylaştırmada Edirne civarını alan Emir Süleyman (1402-1411) Edirne'de Padişahlığını ilan etmişti. Avrupalı tarihçiler, Emir Süleyman'1 da Padişahlık sırasına koymaktadırlar (Ünver,1999: XI). Albümde Süleyman'ın sıralamasının karışmasının sebebi de bundan kaynaklanmaktadır. Resimde özellikle figürlerin giysi betimleri gerçekçi bir üslupla motiflerdeki detaylar gözlemlenebilecek şekilde aktarılmıştır. Figürlerin yüzleri tek bir tipte yapılmamıştır. Kendilerine has karakteristik kaş, göz ve sakal betimleri vardır.

Kıyafet Albümü içerisinde 66 yıl önce öldürülen II. Osman'ın tasviri yer alması ve özellikle '20 yaşında boğulan Sultan Osman' ifadeleri ile anlatılması ilginçtir. Yine aynı şekilde bazı devlet görevlileriyle ilgili açıklamalarda da idam cezalarından bahsedilmektedir. Örneğin, Daye hatun tasvirinde yer alan açıklamada da 'Haremde ölen bütün cariyelerin mal varlıklarl bu kadına kallyor, bu yüzden genellikle haremde boğazlanarak öldürülüyorlar.' ifadesinin yer almaktadır. İlginç bir başka örnek ise, Kazasker tasvirinin ardından, Kazaskerin görevleri anlatılırken, 'Bunları öldürtmek istersek yapamayız, Krala karşı suç işlediğinde Sultan Murat zamanında olduğu gibi öldürülürler' ifadeleriyle ölüm cezalarının işleyişi özellikle vurgulanmıştır (Resim:13). Albümü sipariş eden kişinin Osmanlı devletindeki ceza sistemi dikkatini çektiği için özellikle bu yönlerin yansıtılmasını istediği sonucu çıkartılabilir. 


\section{İSTANBUL'DAN PARIS'E GIZEMLİ BİR YOLCULUK: HÜSEYIN ISTANBULI'YY ATFEDİLEN KIYAFET ALBÜMLERİ}

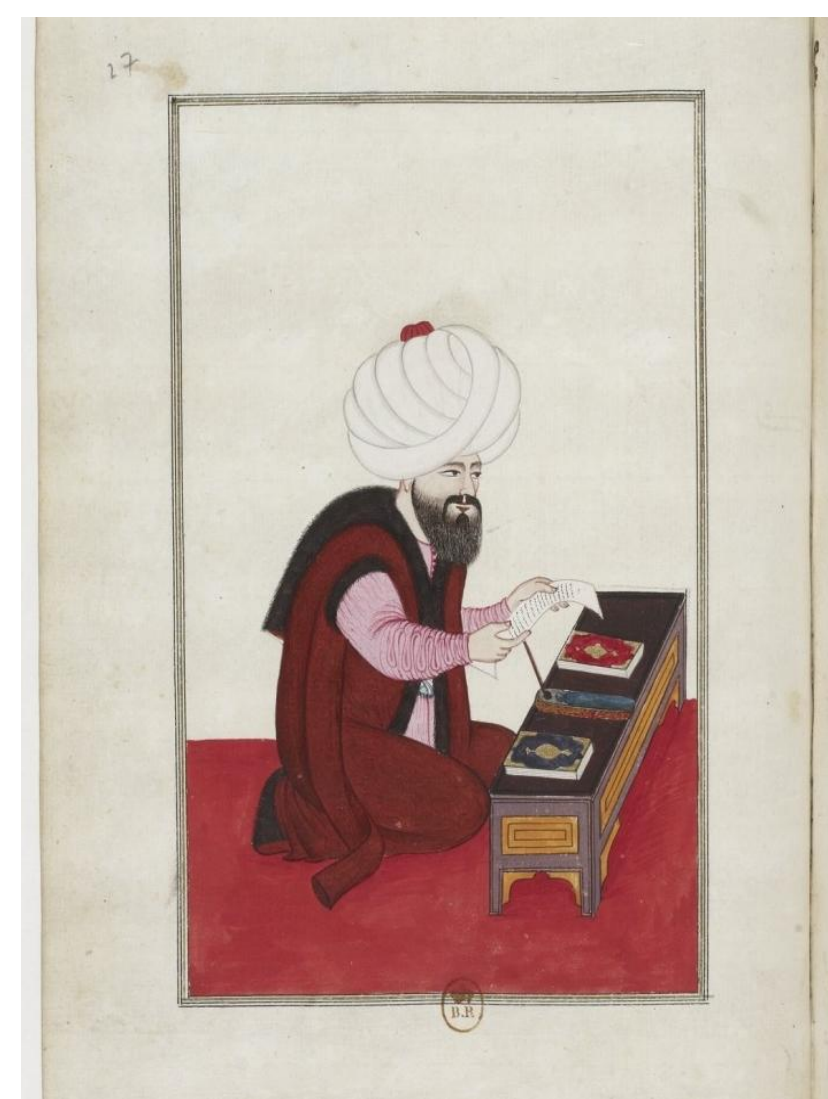

Resim 13. Paris Bibliothèque Nationale de France, N.Od.7, 27.y, 27a,Cadilefkier. Kazasker.

27.y, 27b, İmgenin açıklaması:

'Cadilefkier seconde personne de la Loy, il y en a deux l'un d'Europe v l'autre d'asie. Lors $q u$ 'on veutles faire mourir, on ne le peut faire qu'auparavant on ne leur ait oste leur charge de

Gens de la Loy. Si l'un des deux faisoit quelque crime contre la Loy, on le pileroit dans un mortier, comme il est arrive a un du temps de Sultan Murat.'

'Kazasker, imparatorlukta iki tane bulunur diğeri asya ile ilgilenir, 2.slradadır. Bunlart (kazaskerleri) öldürtmek istersek yapamayız. Bir tanesi krala karşı suç işlediğinde Sultan Murat zamanında olduğu gibi öldürülürler.'

$\mathrm{Bu}$ durum albümün Fransız elçisi tarafından sipariş edildiği tahminini de güçlendirir. Fransa kralına Osmanlı sarayını tanıtırken ceza sistemini ve Osmanlı toplumundaki düzeni de aktarmış olmaktaydı. Albümde saraylı hanım ve hizmetkârını tasvir eden resimde, kumaş motifleri, masadaki porselen vazolar, vazolara yerleştirilen çiçekler ve figürlerin yüzlerindeki doğal ifadeler (Resim:14) ressamın konuyu gözleme dayalı bir günlük yaşam sahnesi gibi ele aldığını göstermektedir (Majer, 2000: 345). Albüm içerisindeki mekân düzenlemeleri, renk uyumları, yumuşak firça darbeleri, göze çarpan gölgelemeler, İstanbuli'nin Avrupalı müşteriler için yaptığı resimlerde, Avrupa resim diline daha yakın çalıştığını düşündürmektedir. Avrupa resim dilini bildiği bazı tasvirlerinde uyguladığı derinlik etkisi ve ikonografik öğelerden 


\section{ISTANBUL'DAN PARIIS'E GIZEMLİ BİR YOLCULUK: HÜSEYIN ISTANBULI'YY ATFEDİLEN KIYAFET ALBÜMLERİ}

anlaşılmaktadır. Örneğin, Avrupalı Derviş tasvirinde, derviş arkaya doğru uzayan bir manzaranın içerisine yerleştirilmiş, renk tonlamalarıyla derinlik etkisi yakalanmıştır ${ }^{7}$ (resim:15).

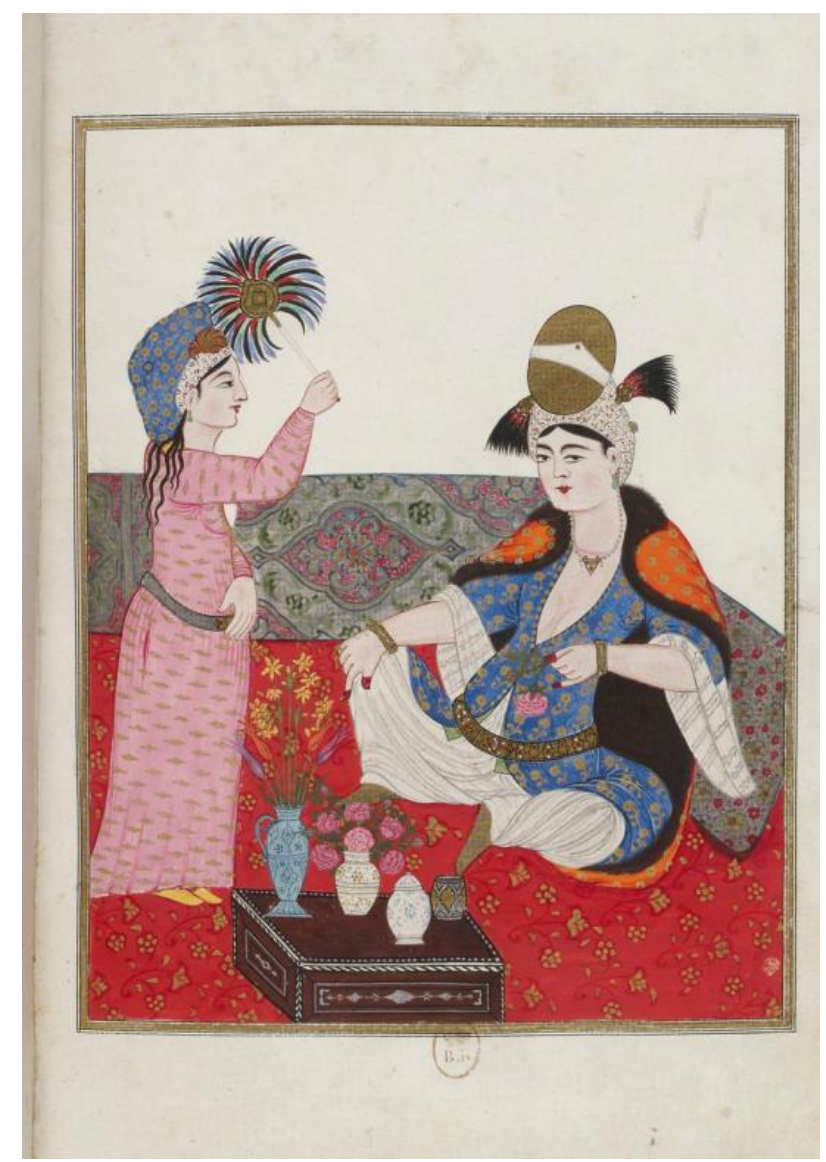

Resim 14. Paris Bibliothèque Nationale de France, N.Od.7, 20.y, 20a, L’ Affeki Sultane ou Premiere Femme du Grand Seigneur. Haseki sultan. 20.y,20b, imgenin açıklaması:

'L' Affeki Sultane ou Premiere Femme du Grand Seigneur La premiere qui a des Enfans masles devient Affeki Sultane. Elle est assise sur un Sofa.'

'Haseki Sultan veya Padişahın birinci en önemli eşi, ilk erkek çocuk doğuran kadına verilen unvan ve divanda oturur.'

\footnotetext{
7 İmgenin Fransızcası: 'Derviche d’Europe ' şeklindedir. Avrupalı Derviş tanım olarak doğru değildir ancak burada ne kastedilmeye çalışıldığını net olarak söylemek güçtür. 'Avrupa'da Derviş’ gibi bir anlamda da kullanılmış olabilir.
} 


\section{ISTANBUL'DAN PARIIS'E GIZEMLİ BİR YOLCULUK: HÜSEYIN \\ ISTANBULI'YY ATFEDİLEN KIYAFET ALBÜMLERİ}

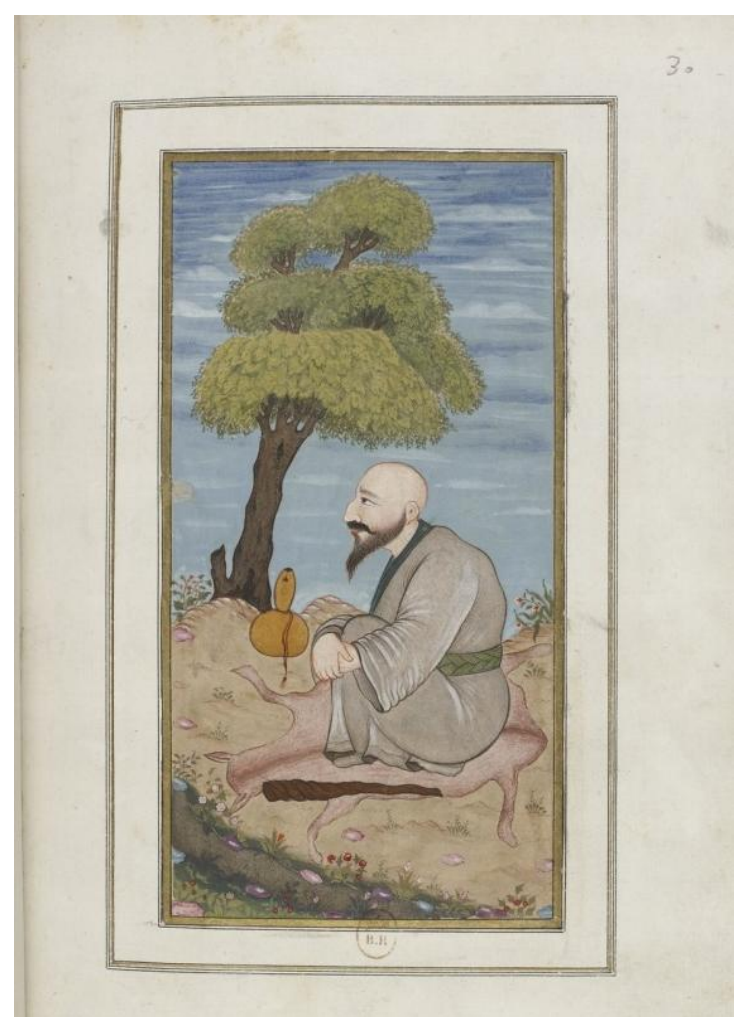

Resim 15. Paris Bibliothèque Nationale de France, N.Od.7, 30.y, 30a, Derviche d' Europe. Avrupa dervişi. ( ? )

N. Od. 6 numaralı albümdeki Haseki Sultan tasvirinde de sultan bir mekân içerisine yerleştirilmiş ve mekânın penceresinden görünen doğa kesiti arkaya doğru uzayarak ve derinleşerek aktarılmıştır (Resim:16). Bu uygulama Avrupa resim dilini bildiğine kanıt olarak gösterilebilir. Yüzyıl içerisindeki diğer albümlerle kıyaslandığında İstanbuli’nin resimdeki ustalı̆̆ dikkat çekmektedir. Albümde imzasının bulunmamasına ya da isminin herhangi bir yerde geçmemesine rağmen albüm resimleri, Hüseyin İstanbuli'nin imzası bulunan ve ona atfedilen diğer işleriyle kıyaslandığında teknik açıdan ve üslup özelliklerinin benzerliği ile albümün ressamının Hüseyin İstanbuli olduğu savını güçlendirmektedir. Fırça tekniğindeki yumuşaklık, portrelerindeki ustalığı ve boyayı incelterek kullanarak yakaladığı tonlamalardaki ustalığı Hüseyin İstanbuli'nin işlerinin hepsinde açıkça gözlemlenebilmektedir. 


\section{İSTANBUL'DAN PARİ'E GIZZEMLİ BİR YOLCULUK: HÜSEYİN İSTANBULI'YE ATFEDILEN KIYAFET ALBÜMLERİ}

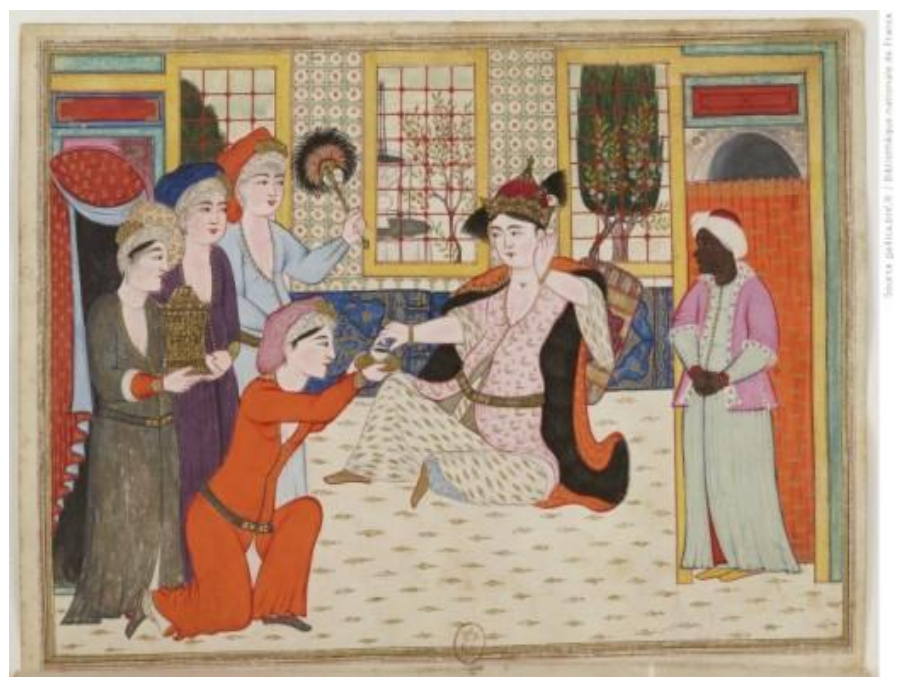

Resim 16. Paris Bibliothèque Nationale de France, N.Od.6, 4.y. Albümün dördüncü tasviri olan bu yaprakta da tasvire dair herhangi bir açıklama bulunmamaktadır.

Hüseyin İstanbuli 17. yüzyıl'ın üçüncü çeyreğinden itibaren Osmanlı resim sanatına yeni bir soluk getirmiştir. Öğrencisi olduğu düşünülen 17. yüzyılın başlarından 1730’a kadar saray da etkin bir nakkaş olan Levni ile bazı eserlerinde benzerlikler bulunmaktadır. Hüseyin İstanbuli'nin VÖN (AF.50) yer alan Silsilenamesinin 16.a yaprağında bulunan IV. Mehmet tasviri ile Levni'nin TSMK bulunan, Kebir Musavver Silsilename'sindeki (A.3109) III. Ahmet tasvirindeki (y.22a) zemin döşemesi, IV. Mehmet'in taht bezemesiyle aynıdır. III. Ahmet'in taht1, tahtta oturuşu, tahtı tutuşu (Resim:17,18) ve iki resmin kompozisyonu birbiri ile aynıdır (İrepoğlu, 1999: 106). Levni’nin yine TSMK (H. 2164) bulunan albümü içerisinde 1b de bulunan Genç Osman tasvirinde de III. Ahmet tasvirindeki aynı kompozisyon kullanılmıştır. Genç Osman'ın tahtı, oturma biçimi, tahttı tutuşu Hüseyin İstanbuli'nin kompozisyonuna benzemektedir (Resim:19).

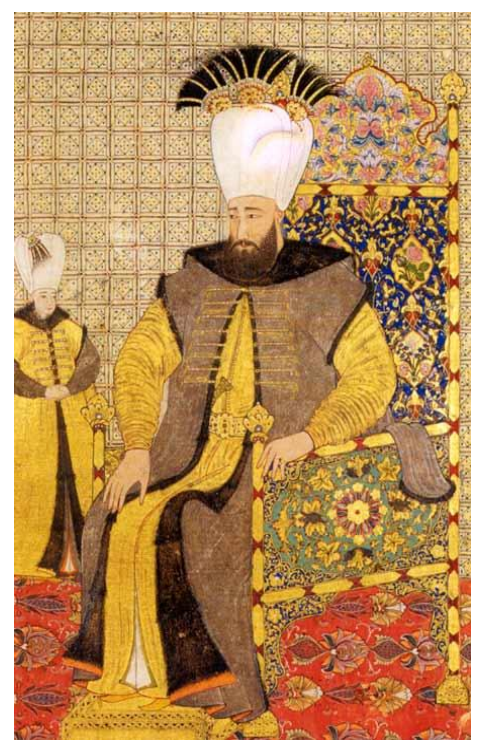




\section{İSTANBUL'DAN PARİ'E GIZZEMLİ BİR YOLCULUK: HÜSEYİN İSTANBULI'YE ATFEDİLEN KIYAFET ALBÜMLERİ}

Resim 17. Levni, Kebir Musavvar Silsilename, A.3109 y.22 a, III. Ahmet. İrepoğlu, Gül. (1999). s.107.

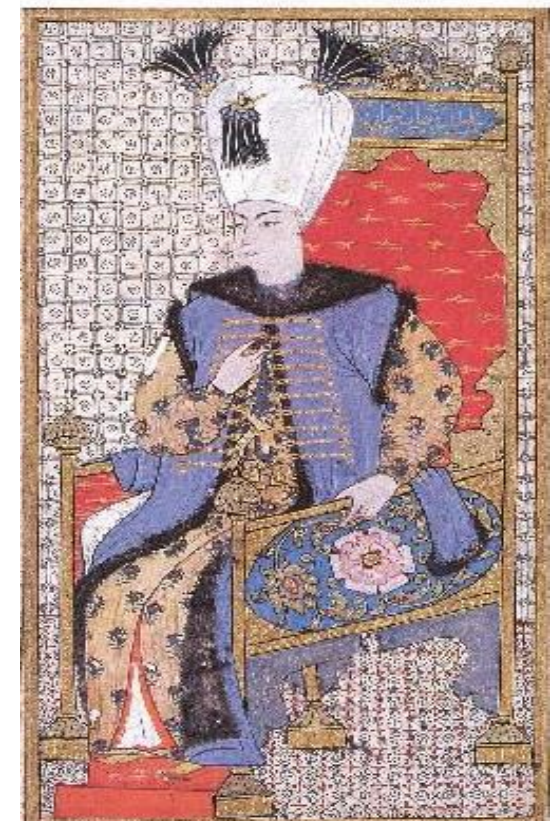

Resim 18. Levni, Topkapı Sarayı Müzesi Kitaplığı, H.2164, y.1b, Genç Osman, İrepoğlu, Gül. (1999). s.105.

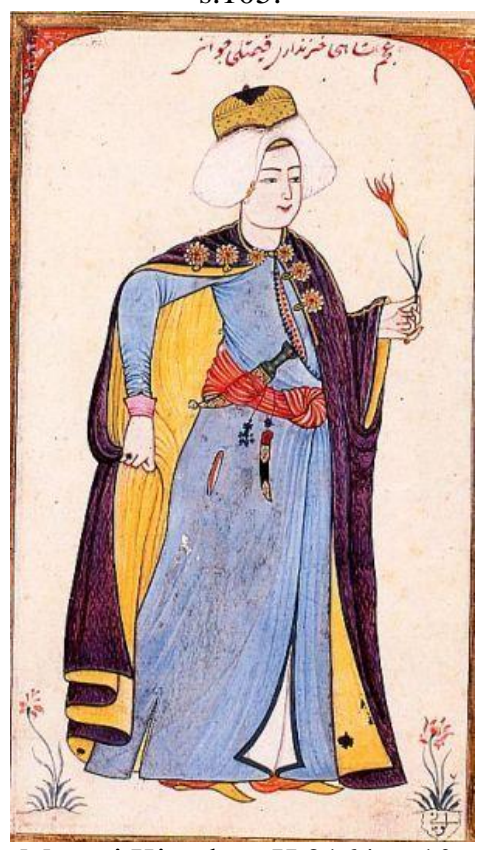

Resim 19. Levni, Topkapı Sarayı Müzesi Kitaplığı, H.2164, y.10a, Acem Şahı Hazinedarı Kıymetli Civanı İrepoğlu, Gül. (1999). s.184.

$\mathrm{Bu}$ benzerlik Hoca- öğrenci ilişkisine işaret edebilir. Ancak Levni'nin saray nakkaşhanesinde kendinden önce çalışmış birinin işlerinden kolaylıkla haberdar olabileceği ihtimali de göz önünde tutulmalıdır. Resim kompozisyon düzeni ve ikonografik benzerlikler dışında, figürlerin benzer karakteristik özellikleri bulunmamaktadır. Levni'nin figürleri, ince bedenli, çekik kaşlı, çekik küçük gözlü, ince ayrık kaşlı, duru pembemsi gölgeli tenleri ile daha 


\section{İSTANBUL'DAN PARİ'E GIZZEMLİ BİR YOLCULUK: HÜSEYİN İSTANBULI'YY ATFEDILEN KIYAFET ALBÜMLERİ}

naif, daha sıcak ve daha estetik figürlerdir (İrepoğlu, 1999: 106). Levni’nin Padişah tasvirleri, Hüseyin İstanbuli’nin padişah tasvirleri kadar idealize edilmemişlerdir. Özellikle Kebir Musavvar Silsilenamesinde (A.3109) Sultan IV. Mehmet tasviri, yerde bağdaş kurmuş otururken aktarılmıştır. Hantal bir görüntüde olan figür İstanbuli'nin IV. Mehmet tasvirleriyle kesinlikle benzememektedir. Figür daha hacimli, yüz hatları daha yuvarlak kaş ve göz betimleri oldukça ayrık ve çekiktir. Hüseyin İstanbuli, batı tekniklerine oldukça aşinadır. Resimlerinde derinlik etkisini başarı ile aktarmaktadır. Boyayı incelterek kullanır ve tonlama etkisini ustaca vermektedir. Levni ile temas halinde hoca-öğrenci ilişkisi içerisinde olduklarını kesin bir yargıyla söylemek güç olsa da Levni'nin İstanbuli'den etkilendiği açıkça gözlemlenmektedir. Hüseyin İstanbuli kendinden sonraki çağa yenilikler kazandırmış önemli bir nakkaştır.

\section{SONUÇ}

16. yüzyıldan itibaren hem Avrupalılar hem de Osmanlı sanatçıları tarafından hazırlanan kıyafet albümleriyle ilgili en önemli sorulardan biri, albümler, çarşıdan mı saraya, saraydan mı çarşıya gidiyordu sorusudur. Albümler sarayın beğenisinin ürünü olarak şekillenip, tasarlanıp çarşı üretimine mi yön veriyordu? Yoksa çarşının kendi dinamiği içerisinde genellikle seri şekilde üretilen bu albümler satın alma yolu ile mi saraya ulaşıyordu. Saray mensubu olan Musavvir Hüseyin İstanbuli, kendisine atfedilen Paris koleksiyonundaki iki kıyafet albümünü çarşıda muhtemelen bağlı olduğu yada kendisine ait olan atölyesinde üretmişti.

O halde saray mensubu olan sanatçılar da çarşı içerisindeki serbest atölyelerde sürekli alıcısı olan bu kıyafet albümlerini seri şekilde üretmekteydi diyebiliriz. Albüm alıcıları, Osmanlı topraklarına gelen elçiler, diplomatlar, gezginler, İstanbul'a görevli olarak gelen askerler, mühendisler, bilim adamları, gözlem için gönderilen komisyonlarda yer alan görevliler, koleksiyonerler ve Krallıkların Osmanlı kültürünü araştırmak üzere özel bir eğitimle yetiştirdikleri doğu uzmanları Osmanlı dünyasına ilgisi olan hükümdarlar için kıyafet albümleri sipariş etmiş veya bizzat beraberlerinde getirdikleri ressamları tarafindan bu albümleri ürettirmişlerdir. Albümlerin neredeyse tamamı Avrupalı alıcılar için hazırlanmıştır.

Musavvir Hüseyin İstanbuli'ye atfedilen Paris koleksiyonundaki kıyafet albümünde albümün, sipariş süreciyle ilgili herhangi bir bilgi bulunmamaktadır. Kıyafet albümleri Osmanlı toplumunun panoramasını sunması özelliği ile ülkeye gelen yabancıların yanlarında götürdükleri önemli koleksiyon parçaları arasındaydı. Bu sebeple o dönem Osmanlı topraklarında bulunan 1686-1688 yılları arasında İstanbul'da görev yapan Fransız diplomat Pierre de Girardin tarafından XIV. Louis'e (1643-1715) II. Süleyman'1 (1687-1691) haremini, sarayını ve Osmanlı devletini tanıtmak için bu kıyafet albümü sipariş edilip XIV. Louis’e 


\section{İSTANBUL'DAN PARİ'E GIZZMLİ BİR YOLCULUK: HÜSEYİN İSTANBULI'YY ATFEDILEN KIYAFET ALBÜMLERİ}

hediye edilmiş olmalıdır. İstanbul'da hazırlanıp ciltlenen bu albümlere ait tek yaprak resimlerinde günümüzde çeşitli müze ve koleksiyonlarda yer alması, bu albümlerin bazılarının özgün hallerini yitirdiklerini düşündürmektedir. Albümlerin alıcısı tarafından özellikle çeşitli kişilere hediye etmek amaçlı tek yapraklar halinde dağıtılabileceği gibi, ilerleyen zamanda koruma koşullarının yetersizliğinden kaynaklı dağılmışta olabilir.

Kıyafet albümlerindeki resimler ve resimlerle ilgili açıklamalar da, Avrupalı alıcının, Osmanlı dünyasında en çok merak ettiği ya da dikkatini çeken durumlar çerçevesinde şekillenmiştir. Musavvir Hüseyin İstanbuli’ye atfedilen Od.7 numaralı kıyafet albümünde, Padişah, vezir, saray görevlileri, kadın ve erkekler, din adamları, hokkabazlar, dervişler, bir mekân kesiti içerisinde betimlenmiş iki genç âşık gibi pek çok kesimden insana ait tasvirlerin yer aldığı klasik bir resim repertuarı vardır ancak, imgelerin açıklamalarında sıkça ölüm cezalarından bahsedilmesi dikkat çeken noktalar arasındadır. Sanki bilinçli olarak Osmanlı devleti ceza sistemi içerisinde özellikle ölüm cezaları vurgulanmak istenmiştir. II. Osman'ın idam edilmesinden bile bahsedilmiş ve tasviri eklenmiştir. Bu nokta albümün ilgi çekici özelliklerinden biridir.

Ayrıca albümdeki, haseki sultan ve onun hizmetlileri, çengiler ve bazı halktan kadın figürlerinin tasvirinin diğer kıyafet albümündeki kadın tasvirlere göre daha canlı ve dinamik yapılması Kral XIV. Louis'in kadınlara duyduğu ilgiye bağlanabilir. Albüm, XIV. Louis'in dikkati çekmek için özellikle kadın tasvirleri ve Osmanlı yönetim sistemiyle ilgili bilgiler içerecek şekilde sipariş edilmiş olabilir. Musavvir Hüseyin İstanbuli'nin kıyafet albümlerinde imzasının bulunmamasına ya da isminin herhangi bir yerde geçmemesine rağmen albüm resimleri, Hüseyin İstanbuli'nin imzası bulunan ve ona atfedilen diğer işleriyle kıyaslandığında teknik açıdan ve üslup özelliklerinin benzerliği ile albümün ressamının Hüseyin İstanbuli olduğu savını güçlendirmektedir. Fırça tekniğindeki yumuşaklık, portrelerindeki ustalığı ve boyayı inceltilmiş şekilde kullanarak yakaladığı tonlamalardaki başarısı Hüseyin İstanbuli'nin işlerinin hepsinde açıkça gözlemlenebilmektedir. 1688 tarihli ana albüm ile 1720 tarihli diğer albümün resimleri kıyaslandığında, vezir, iç oğlanlar, şahinci başı, saray ağası, yelpaze taşıyan görevli, kırmızı feraceli kadın, kazasker ve müftü gibi tasvirleri birebir sayılacak derecede aynıdır. Bahsi geçen tasvirlerin, renk, kompozisyon ve kaş, göz- yüz betimleri arasındaki büyük benzerlik 1720 (Od.6) tarihli olan albümün diğer albümden bakılarak kopya edildiği ve muhtemelen daha sonra tarih eklenerek kullanıldığını düşündürür.

Hüseyin İstanbuli saray sanatçısı olmasına rağmen kıyafet albümü üreterek iki kültür içinde çalışabilen çok yönlü bir sanatçı olduğunu kanıtlamıştır. Albümlerin Hüseyin İstanbuli 


\section{İSTANBUL'DAN PARİ'E GIZZMLİ BİR YOLCULUK: HÜSEYİN İSTANBULI'YE ATFEDİLEN KIYAFET ALBÜMLERİ}

tarafından resmedilmiş olmasının heyecan verici taraflarından biri İstanbul sanat ortamı içerisinde saray nakkaşhanesi mensubu sanatçılarında çalıştığının düşünülmesi olmuştur. XVI. Louis'in Osmanlı toplumuna duyduğu merakın sanat piyasasını da şekillendirdiğini söylemek mümkündür. İncelemeler sonucu Hüseyin İstanbuli'nin saray içinde ve dışında oldukça aktif bir sanatçı olduğunu söylemek yanlış olmayacaktır. İmzaladığı eserlerinde de özellikle 'musavvir' sıfatını kullanarak kendisinin suret yaratma yani resmetme ustalığına vurgu yapmıştır. Albümün XVI. Louis için bizzat İstanbuli tarafından hazırlandığını düşündüren önemli bir neden de İstanbuli'nin saray içinde Padişaha yakın bir konumda bulunmasıdır. Dolayısıyla hem saray hayatını bilen hem yetenekleriyle ünlü bir sanatçı, Fransız elçisi için bu albümü emanet edecek doğru adres olmuş olmalıdır. Kıyafet albümleri sipariş süreci ve bani-sanatçı ilişkisi içerisinde Osmanlı resim sanatı bağlamında önemli ipuçları içermektedir. Ayrıca Avrupa'daki Türk akımı içerisinde de önemli bir yere sahiptir. Fransa'da albümün gittiği yıllarda Türk kahvesi içme geleneği, Osmanlı giyim modası etkileri ve Osmanlı toplumunun hayatından kesitlerin aktarıldığı tiyatro oyunlarına sıkça rastlanmaktadır.

\section{Kaynakça}

Abdurrahim, A., 2017. Osmanlı Kitap Sanatlarında Silsilename Geleneği ve Resimlendirilmesi, Mimar Sinan Üniversitesi, Sosyal Bilimler Enstitüsü, İstanbul

And, M., 1985. “17. Yüzyıl Türk Çarşı Ressamları”, Tarih ve Toplum, S.16, s.40-45.

And, M., 1990. “17. Yüzyıl Türk Çarşı Ressamları ve Resimlerinin Belgesel Önemi”, kültür ve Sanat, S.8, s.5-11.

And, M., 2009. Çarşı Ressamları, Yapı Kredi Yayınları, İstanbul.

Anonim. Pabuç, (2014), İstanbul: Sadberk Hanım Müzesi Sergisi Kataloğu.

Bağcı, S.; Çağman, F.; Renda, G.; Tanındı, Z; 2006. Osmanlı Resim Sanatı, Kültür ve Turizm Bakanlığı Yayınları, İstanbul.

Bayram, S., 1981. "Musavvir Hüseyin Tarafindan Minyatürleri Yapılan Ve Halen Vakıflar Genel Müdürlügü̈ Arşivinde Muhâfâza Edilen Silsile-Nâme", Vakıflar Dergisi, S.13. s.253-338.

Dağl1, Yücel. K., 2003. Günümüz Türkçesiyle Evliya Çelebi Seyahatnamesi: İstanbul, Yap1 Kredi Yayınları, İstanbul.

İnal, G., 1984. Tek Figürden Oluşan Albüm Resimleri. Arkeoloji-Sanat Tarihi Dergisi, s.3, İzmir: Ege Üniversitesi Yayınları.

İrepoğlu, G., 1999. Levni, Nakış, Şiir, Renk, T.C Kültür Bakanlığı Yayınları, İstanbul.

Küçükhasköylü, N., 2010. Osmanlı Kıyafet Albümleri., Hacettepe Üniversitesi, Sosyal Bilimler Enstitüsü, Ankara.

Mahir, B., 2005. Osmanlı Minyatür Sanatı, Kabalcı Yayınevi, İstanbul.

Majer, H., 1999. Individualized Sultans and Sexy Women. The Works of Musavvir Hüseyin and their East-West Context, Art Turc. 10th İnternational Congrees of Turkish Art/10e Congres international d'art turc, Geneve-Geneva, 17-23 Septembre.Geneve. 


\section{ISTANBUL'DAN PARİS'E GİZEMLİ BİR YOLCULUK: HÜSEYIN ISTANBULI'YE ATFEDILEN KIYAFET ALBÜMLERİ}

Majer, H., 2000. 'Yaygınlaşan Gelenek(1600-1700): Yeni Yaklaşımlar', Padişahın Portresi Tesavir-i Ali Osman, İstanbul: İş bankası Yayınları, İstanbul.

Osman, R., 1989. Edirne Saray1, Türk Tarih Kurumu, Ankara.

Oruç, G., 2017a. Avrupa'nın Moda Kataloğu: Osmanlı Kıyafet Albümleri, Genç Sanat Dergisi, S.260, s.36-42.

Oruç, G., 2017b. Baniler, Sanatçılar, Koleksiyonerler, Koleksiyonlar (11-13 Mart 2015), 7. Uluslar arası Genç Sanat Tarihçiler Sempozyumu. Sempozyum Bildiri Kitabı. Ankara Üniversitesi Yayınları, Ankara.

Pietro della V., 1989. The Journals of Pietro della Valle, the Pilgrim, ed. ve çev. George Bull, Londra.

Renda, G., 1977. Batılılaşma Döneminde Türk Resim Sanatı (1700-1850), Hacettepe Üniversitesi Yayınları, Ankara.

Renda, G., 1998. 17. Yüzyı1'dan bir Grup Kıyafet Albümü, 17. Yüzyıl Osmanlı

Kültür ve Sanat1, Sempozyum Bildirileri, 153-178, İstanbul: Sanat Tarihi Yayınları

Renda, G., 2009. Sanatta Etkileşim, Osmanlı Uygarlığı (2. Cilt, s.1100-1122). İstanbul, Kültür ve Turizm Bakanlığ 1 Yayınları.

Schick, L., 2003. Osmanlı Kıyafet Albümleri, Toplumsal Tarih,S.116. s.115-120.

Schneider, J., 2000. Fantastical Colors in Foggy London: The New Fashion Potential of the late Sixteenth Century, Metarial London, ed. Lena Cowen Orlin, Pennsylvania.

Silsilename., 2000. Genealogical Tree, Ankara.

Subhatu'1 Ahbar., 1968. Subhatu'l Ahbar. İstanbul.

Ünver, Süheyl., 1999. Geçmiş Yüzyıllarda Kıyafet Resimlerimiz. Türk Tarih Kurumu, Yayınları, Ankara.

Versailles., 1999. Topkap1 a Versailles. Tresors de la Cour ottomane, Sergi Kitab1, Musee national des chateux de Versailles eet de Trianon, Paris.

Wılliams, H., 2014. 18. Yüzyılda Avrupa'da Türk Modas1 Turquerie. Yap1 kredi yayınları. İstanbul. 